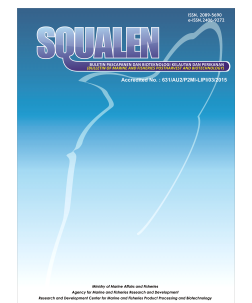

\title{
FATTY ACID PROFILE, CAROTENOID CONTENT, AND IN VITRO ANTICANCER ACTIVITY OF KARIMUNJAWA AND LAMPUNG SEA CUCUMBER
}

\author{
Ekowati Chasanah ${ }^{* 1)}$, Yusro Nuri Fawzya1', Kustiariyah Tarman ${ }^{* 2)}$, \\ Hedi Indra Januar ${ }^{1}$, and Muhammad Nursid ${ }^{1}$ \\ ${ }^{1}$ Research and Development Center for Marine. and Fisheries Product Competitiveness and Biotechnology, \\ Jalan KS Tubun Petamburan VI, Jakarta, 10260, Indonesia; \\ ${ }^{2}$ Faculty of Fisheries and Marine Sciences, Bogor Agricultural University, Jalan Raya Dramaga Kampus IPB, \\ Bogor 16680, Indonesia \\ Article history: \\ Received: 9 September 2016; Revised: 28 October 2016; Accepted: 30 November 2016
}

\begin{abstract}
Fatty acids and carotenoid has been known as an anticancer agent on both preventing and treating cancer disease. This study was conducted to analyze the fatty acid profile, carotenoid and in vitro anticancer activity of 12 sea cucumber harvested from Karimunjawa and Lampung waters. The aim of the study was to determin the potency of sea cucumbers as raw material for nutraceutical products. Fatty acid profile and carotenoid content were characterized by gas chromatography and spectrophotometry techniques, while in vitro anticancer activity was assessed by MTT assay against cervix (HeLa), breast (T47D and MCF-7) and colon (WiDR) cancer cells. Results of the study showed polyunsaturated fatty acid (PUFA) dominated the composition of fatty acids in the samples from both locations. Holothuria sp. was detected to contain the highest amount of carotenoid. Furthermore, the highest in vitro anticancer activity was detected also in the sample of Holothuria sp. The activity of $30 \mathrm{ppm}$ Holothuria sp. extract against HeLa cell was detected to be almost equal to the $5 \mathrm{ppm}$ doxorubicin control. Concentration of $5 \mathrm{ppm}$ Holothuria sp. extract also showed positive result in killing 50\% of MCF-7 and T47D, but capable to $100 \%$ kill HeLa and WiDR cells. At concentration of $25 \mathrm{ppm}$, the extract was able to kill all the 4 cells tested. Statistical analysis showed the amount of carotenoid and two particular fatty acid compounds (docosadienoic and eicosapentaenoic acid) significantly $(\mathrm{P}<0.05)$ contributed to the cytotoxic activity that was found in the sea cucumber samples. Those compounds were found in highest concentration from Holothuria sp harvested from Lampung waters, thus being the most prospective raw material for nutraceutical or functional food ingredient with anticancer potency.
\end{abstract}

Keywords: anticancer, carotenoid, fatty acids, sea cucumber

\section{Introduction}

According to FAO statistics, Indonesia is the biggest exporter of dried sea cucumber worldwide, and about $40-80 \%$ are exported to China, Hong Kong SAR, Japan, Republic of Korea, Taiwan, Singapore, Malaysia and Australia (Bordbar, Farooq \& Nazamid $\mathrm{S}, 2011)$. Well known as teripang, trepang, bechede-mer, or gamat, sea cucumbers have been utilized not only as food but also for traditional medicine in Middle East and Asian countries, including Indonesia. Among the total number of existing sea cucumber species in the world, i.e about 1250 species (Bordbar et al., 2011), Darsono (2007) reported that there were
53 species of sea cucumber in Indonesia, and 29 of them are internationally traded which are mostly Holothuriidae and Stichopodidae. In Indonesia, Lampung and Karimunjawa waters are locations where sea cucumber sources has been harvested for commercial dried sea cucumber product. Recently, a number of publications reported that some sea cucumber species has been applied for pharmaceutical and cosmetical used, and has a promising future as important component for functional food products (Janakiram, Mohammed, \& Rao, 2015; Ridhowati, Zakaria, Syah, \& Chasanah, 2014). Many publications report the potency of sea cucumber as antitumor agent and their possibility applications to

\footnotetext{
${ }^{*}$ Corresponding author.

E-mail: ekowatichasanah@gmail.com
} 
the prevention and treatment of human diseases, including cancers (Janakiram et al., 2015; Nursid, Maharani, A.P., Riyanti, \& Marraskuranto, E. 2016; Pérez-Espadas et al., 2014). However, exploration of sea cucumbers originating from Lampung and Karimunjawa waters, particularly as anticancer agent, is still limited.

Fatty acid profile in sea cucumber is considered unique. As bottom sediment feeder organism, sea cucumber is considered healthy food that contains a branched chain fatty acid that has important role in repairing tissue and other important role to keep heart healthy and minimize cancer risk (Sicuro et al., 2012). The PUFA (poly unsaturated fatty acid) such as EPA (eicosa pentaenoic acid) and DHA (docosahexaenoic acid) which is usually abundant in deep fish is reported to have anticancer activity both preventing and treating the cancer (Jing, Wu, \& Lim, 2013; Vaughan, Hassing, \& Lewandowski, 2013). Yoo et al. (2007) reported that three free fatty acids such as palmitic acid, (Z)-9octadecenoic acid and octadecenoic acid from Protaetia brevitarsis larva (PBL) are identified as bioactive compound against various cancer cell lines. Meanwhile Januar et al. (2014) reported that stearic acid was found to be an active substance isolated from sea cucumber against cancer cell line MCF-7 with $\mathrm{IC}_{50}$ of $10.32 \mathrm{ppm}$.

Tetraterpenoids or carotenoids is defined as organic pigments; in sea cucumber, they are obtained from plants and algae, as well as several bacteria and fungi they consumed as debris. It is usually related well to the biopotency of the sea cucumber such as antioxidant, antibacteria, and antitumor. Ibrahim (2012) reported that carotenoid in 3 Holothurian from Egyptian waters had a role as antibacterial agent against $S$. aureus ATCC 6538, while Dang et al. (2007) reported that $H$. scabra, H. leucospilota and Stichopus chloronotus harvested from Malaysian waters were potential sources of natural antioxidant and anticancer agents.
WHO (2014) reported that breast, colorectum and cervical cancer are the dominant cancer caused death in Indonesia. For about 92,200 women deaths, $21.4 \%$ was caused by breast cancer, $10.3 \%$ by cervix uteri cancer and $9.5 \%$ by colorectum cancer. Therefore, many studies have great attention to find sources of natural products which have cytotoxic activity against cancer. The objective of the research was to study fatty acid and carotenoid profile of the sea cucumber from Karimunjawa and Lampung waters against 4 cell cancer lines.

\section{Material and Methods}

Sample collection and preservation. Live sea cucumber were bought from Karimunjawa and Lampung (Figure 1) fisherman on April 2013. There were 12 species of sea cucumbers (Figure 2) commonly caught and commercially marketed as dried sea cucumber in Karimunjawa and Lampung, the two important sea cucumber sources in Indonesia. In Karimunjawa, the dominant sea cucumber marketed was Stichopus, while from Lampung waters, the sea cucumber caught and marketed were relatively varied. Out of 7 sea cucumber samples from Karimunjawa were 4 Stichopus sp. (K1, K2, K3, K6), Stichopus ocellatus (K4), S. vastus (K5) and Actinopyga lecanora (K7), while from Lampung waters, the 5 sea cucumber samples were 2 Stichopus sp. (L1, L3), 1 Actinopyga sp (L2) and 2 Holothuria sp. (L2, L4). The samples were divided into two parts. The first part was taken for fatty acids profile, carotenoid content, and cytotoxic analysis. These samples were cleaned, degutted, and preserved at $-80^{\circ} \mathrm{C}$ under liquid nitrogen. The second part was taken for taxonomical analysis. Raw samples were chilled in coolbox using ice and taxonomic analysis was conducted in Laboratory of Fisheries, Bogor Agricultural University based on morphological characteristics, including dorsal and ventral surface colors (were immediately recorded after

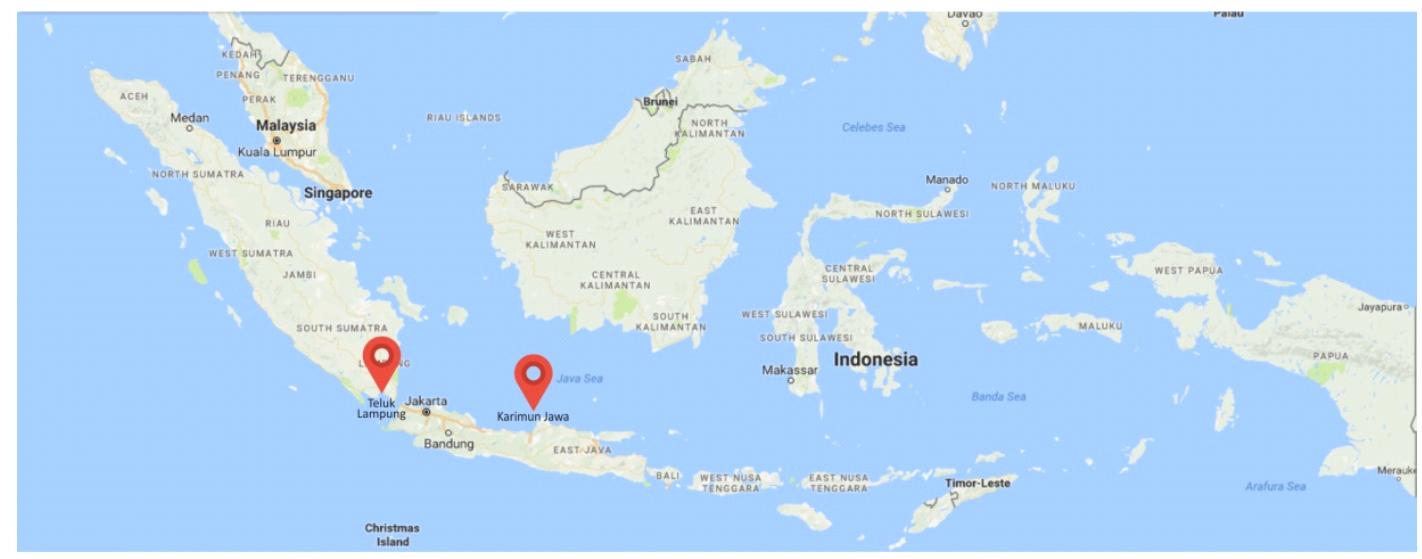

Figure 1. Sampling location (Lampung and Karimunjawa). 

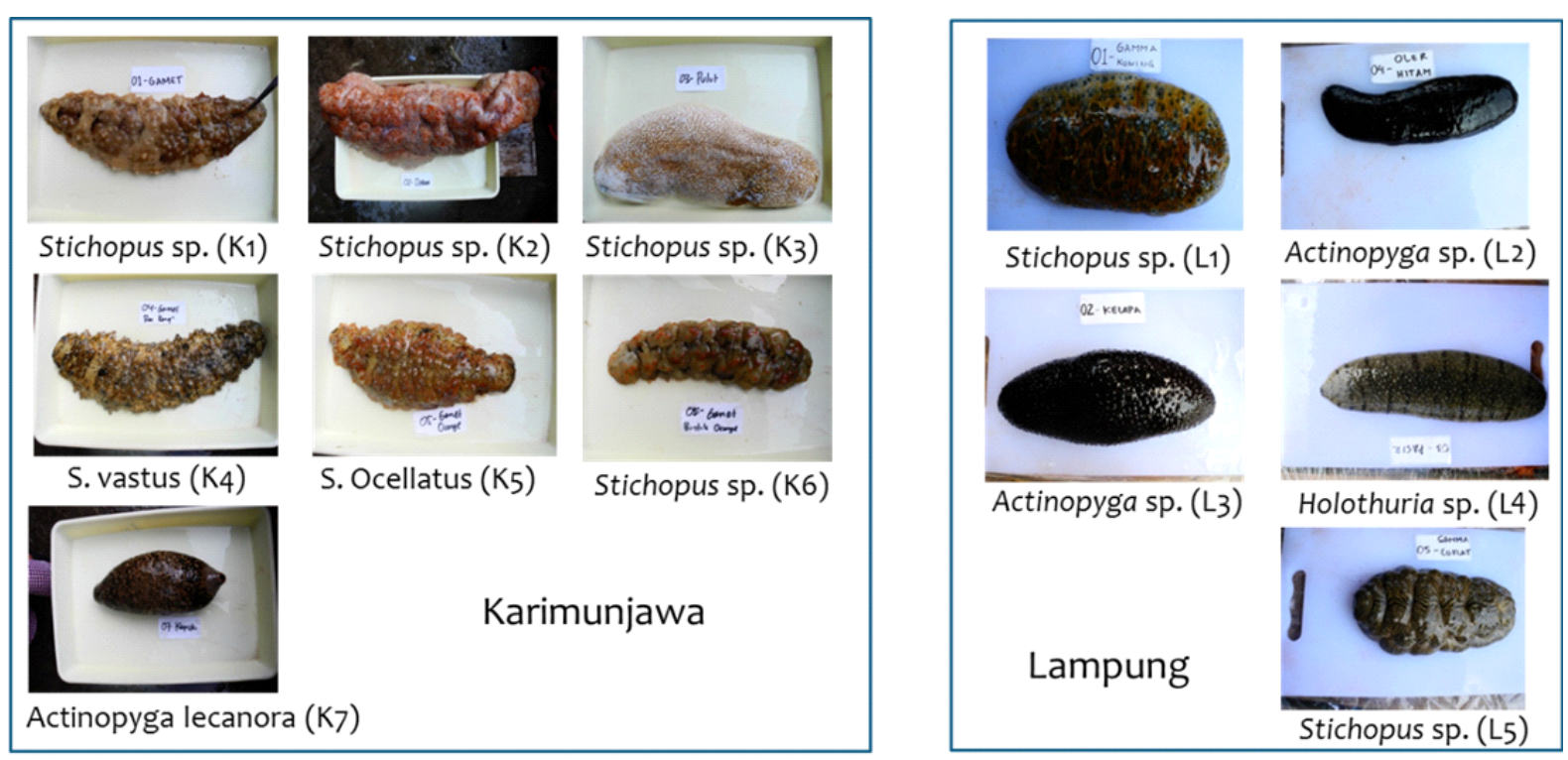

Figure 2. Sea cucumbers from Karimunjawa and Lampung waters.

collection), tentacle type, number of calcareous rings, respiratory trees and gonads and types of spicules.

Fatty acid profile. Fatty acid was extracted from the fresh thawed sample according to Jensen (2008). The profile of fatty acids was analyzed by Gas Chromatography (GC) technique, with Flame lonization Detector (FID) and Supelco 37 FAME Mix (CRM57885) fatty acids standard following to O'Fallon, Busboom, Nelson, \& Gaskins, (2007).

Carotenoid analysis. Cleaned fresh $100 \mathrm{~g}$ samples were extracted with $250 \mathrm{~mL}$ ethanol. Extraction process was repeated twice and solvent removed under reduced pressure by rotary evaporator and freeze dried. The analysis of carotenoid content had been conducted by UV-Vis spectrophotometry assay. A five (5) $\mathrm{mg}$ dried extract was dissolved in $10 \mathrm{~mL}$ methanol (p.a.) and the total carotenoid was calculated according to Lichtenthaler \& Buschmann (2001) equation. The correction of blank absorption was analyzed before samples reading and automatically calculated in the instrument software during samples analyses.

$$
c=\frac{\begin{array}{c}
\left(1000 \times A_{470}\right)-\left[1,63 \times\left(16,72 A_{665,2}-9,16 A_{652,4}\right)\right. \\
\left.+104,96 \times\left(34,09 A_{653,4}-15,28 A_{665,2}\right)\right]
\end{array}}{221}
$$

Cytotoxicity against cell line. A five (5) $\mathrm{mg}$ dried extract was dissolved in $10 \mathrm{~mL}$ acetone. The process was repeated two times. The acetone fractions was dried by rotary evaporator and freeze dryer. Cytotoxicity test was performed using 3-[4,5dimethylthiazol-2-yl]-2,5-diphenyl-tetrazolium bromide (MTT) (Sigma) assay according to Ebada, Edrada, Lin, \& Proksch, (2008). First screening of the sea cucumber extract was conducted using HeLa cells at extract concentration of $30 \mathrm{ppm}$. The highest cytotoxic extract was further tested on 4 tumor cell lines, i.e T47D (breast cancer), MCF7 (breast cancer), HeLa (cervix cancer), and WiDr (colon cancer) using serial doses. A commercial cytotoxic agent (doxorubicin) was used as positive control to compare the level of cytotoxicity. All analyses were conducted in duplicates and the result was presented in average of the duplicate measurements.

Statistical Analysis. All data were log transformed to satisfy the requirement of normally distributed data in statistical multivariate analysis. The assessment of data normality was conducted using the ShapiroWilk W test. Multivariate stepwise regression analysis was employed to detect the relationship between fatty acid profile, carotenoid content, and in vitro anticancer activity. Fatty acid components and carotenoid content were independent variables and cytotoxicity was dependent variables. Statistical analyses were conducted with Statistica Software v10.

\section{Results and Discussion}

\subsection{Fatty Acids Profile}

Fatty acid profiles of all sea cucumber studied showed that the lipid was dominated by polyunsaturated fatty acid (PUFA), both sea cucumber harvested from Lampung and Karimunjawa waters (Figure 3). The highest PUFA content was in L4 sample (Holothuria sp.) harvested from Lampung waters (Figure 3). Among PUFA, $\gamma$-linoleic acid; arachidic $\operatorname{acid}(18: 3 \mathrm{n} 6 ; 20)$ was the highest $(81.58 \mathrm{mg} / 100 \mathrm{~g}$ fresh 


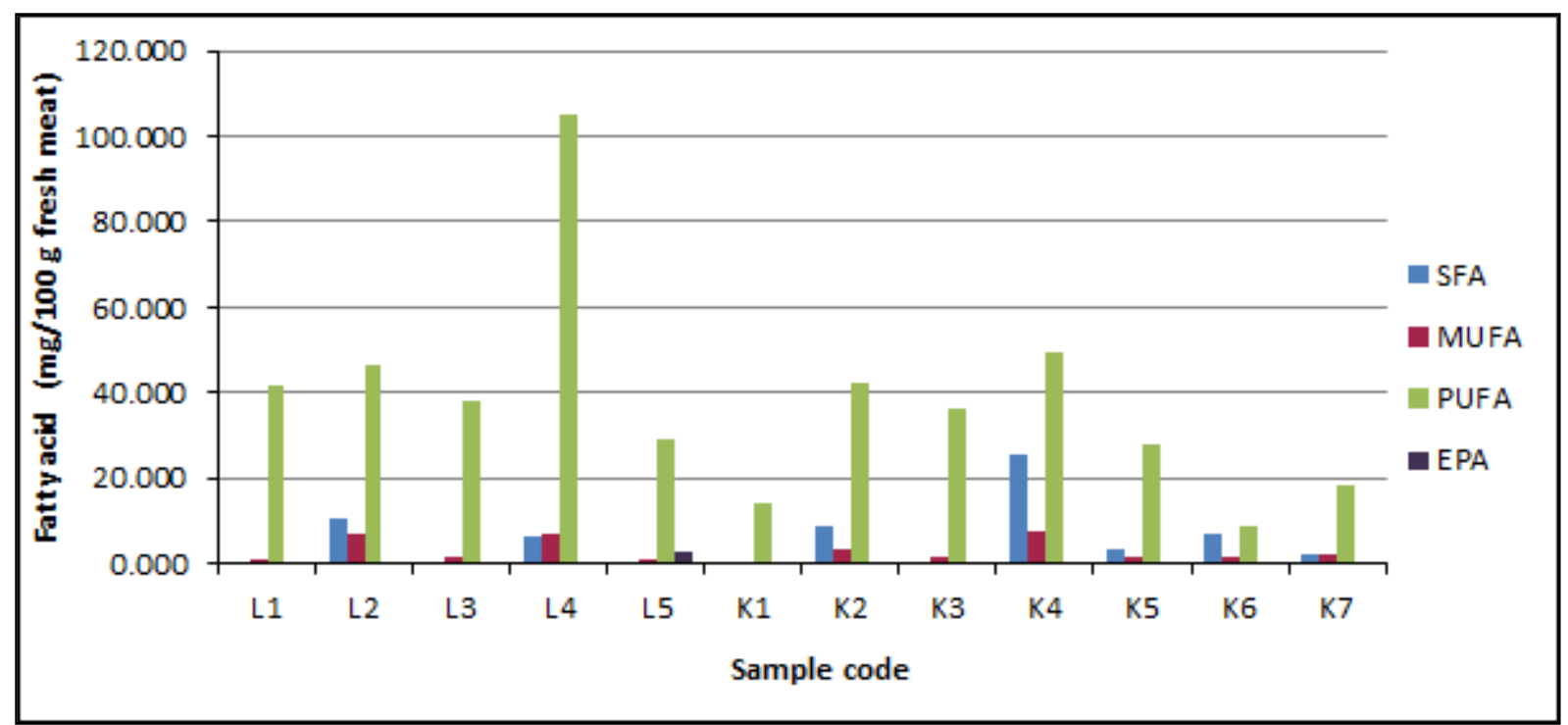

Figure 3. Fatty acid (mg/100 $\mathrm{g}$ fresh tissue) profile of sea cucumber from Karimunjawa $(\mathrm{K})$ and Lampung (L) waters (L1, L2 : Stichopus sp.; L4: Holothuria sp.; L3, L5: Actinopyga sp.; K 1, 2,3, 6: Stichopus sp.; K4: Stichopus vastus; K5: Stichopus ocellatus; K7: Actinopyga lecanora).

meat, WB), followed by cis- $5,8,11,14,17$ Eicosapentanoic acid (20:3n3) EPA (10.528 mg/100 $\mathrm{g}$ fresh meat), Arachidonis acid (20:3n3) $(0.858 \mathrm{mg} /$ $100 \mathrm{~g}$ fresh meat) and 13,16-Docosadienoic acid (22:02) $(0.728 \mathrm{mg} / 100 \mathrm{~g}$ fresh meat) and cis-11,14,17Eicosatrienoic acid (20:3n3) $(0.484 \mathrm{mg} / 100 \mathrm{~g}$ fresh meat). The highest EPA was detected in L5 (Stichopus sp.) followed by L4 and L2 (Actynophyga sp.) (Table 1). However, the sea cucumbers studied were poor of docosahexanoic acid (DHA).

Sea cucumber harvested from Lampung waters contained more PUFA than those from Karimunjawa waters. Sea cucumber from Lampung waters contained more arachidonic acid content, being the highest were Stichopus sp. (L1) and Holothuria sp. (L4), while those from Karimunjawa contained less in those two fatty acids. This study was in line with Svetashev, Levin, Cham, \& Do, (1991) who reported that the major fatty acids discovered in almost all species of sea cucumber was PUFA. Sicuro et al. (2012) also reported that EPA was dominant in PUFA contained in sea cucumber while this study found that $\gamma$ Linoleic; Arachidic (18:3n6 ; 20) was dominat fatty acid among PUFA content. Svetashey et al. (1991) and Ridzwan et al. (2014) found that the dominant PUFA in their sea cucumber studied was arachidonic acid ( $\omega-6$ acid).

This study found SFA was dominant after PUFA (Figure 3), being the highest was in sample K4 (Stichopus vastus) followed by sample L2 (Actinopyga sp.) and K2 (Stichopus sp). Among SFA, palmitic acid was the dominant fatty acid. Study on sea cucumber harvested from Kendari surrounding waters
(Fawzya, Januar, Susilowati, \& Chasanah, 2015) reported that SFA was more dominant than PUFA and MUFA in the sea cucumber $B$. argus, $H$. fuscogilva, $T$. ananas. From this results, it can be inferred that different habitat, although from the same species, could produce sea cucumber with different fatty acid profile, showing that waters and its environmental from where the sea cucumber harvested has an important role in the chemical composition especially in this case was fatty acid profile. Postharvest handling and processing also influence the sea cucumber lipid quality, especially the PUFA which will very prone undergo oxidative changes, causing decreasing the PUFA content. Wen et al. (2010) reported that PUFA was the least in dried sea cucumber and MUFA was dominant in 8 dried sea cucumber followed by SFA. Chemical composition, nutritional status of the sea cucumber including lipid and fatty acid profile was also influenced by animals feeding, physiological characteristics, life cycle and habitat of the species where the sea cucumber has been harvested (Aidin et al., 2011; Neto et al., 2006; Vergara \& Rodríguez, 2016).

\subsection{Carotenoid Content}

Figure 4 showed that the carotenoid of the sea cucumber from Lampung were $11-764 \mathrm{pg} / \mathrm{g}$ (WB). Meanwhile sea cucumber harvested from Karimunjawa had carotenoid of about $20-108 \mathrm{pg} / \mathrm{g}$ (WB). From this data, it can be suggested that sea cucumber from Lampung waters had higher total carotenoid than those from Karimunjawa waters. Among the sea cucumber analyzed, L3 sample, Actinopyga sp. from 
Table 1. PUFA profile of sea cucumber from Karimunjawa (K) and Lampung (L) waters (L1, L2: Stichopus sp.; L4 : Holothuria sp.; L3, L5 : Actinopyga sp.; K 1, 2,3, 6: Stichopus sp.; K4: Stichopus vastus; K5: Stichopus ocellatus; K7: Actinopyga lecanora)

\begin{tabular}{|c|c|c|c|c|c|c|c|c|c|c|c|c|}
\hline $\begin{array}{l}\text { PUFA mg/100 g } \\
\text { fresh meat }\end{array}$ & L1 & L2 & L3 & L4 & L5 & K1 & K2 & K3 & K4 & K5 & K6 & K7 \\
\hline Linolelaidic (18:2n6) & 0 & 1.01 & 0.38 & 1.19 & 0 & 0 & 0.71 & 0 & 1 & 0 & 0 & 0 \\
\hline Linoleic (18:2n6) & 0.59 & 1.71 & 0.62 & 1.06 & 0.39 & 0.39 & 1.5 & 0.85 & 1.81 & 0.64 & 0.47 & 0.61 \\
\hline $\begin{array}{l}\text { gamma-Linoleic; } \\
\text { Arachidic (18:3n6; 20) }\end{array}$ & 33.64 & 28.85 & 28.67 & 81.58 & 22 & 12.53 & 32.02 & 32.43 & 42.3 & 24.91 & 8.25 & 15.22 \\
\hline alpha-Linoleic (18:3n3) & 0.87 & 7.14 & 3.64 & 8.1 & 0.71 & 0 & 5.37 & 3.31 & 3.42 & 2.12 & 0 & 2.38 \\
\hline $\begin{array}{l}\text { cis-5,8,11,14,17- } \\
\text { Eicosapentaenoic } \\
(20: 3 n 3)\end{array}$ & 4.83 & 6.19 & 3.87 & 10.53 & 2.94 & 1.51 & 2.64 & 0 & 0 & 0 & 0 & 0 \\
\hline $\begin{array}{l}\text { cis-11,14,17- } \\
\text { Eicosatrienoic; Behenic } \\
(20: 3 n 6 ; 22)\end{array}$ & 0 & 0 & 0 & 0 & 0 & 0 & 0 & 0 & 0 & 0 & 0 & 0 \\
\hline $\begin{array}{l}\text { cis-8,11,14,17- } \\
\text { Eicosatrienoic (20:3n3) }\end{array}$ & 0.68 & 0.71 & 0 & 0.48 & 0.43 & 0 & 0 & 0 & 0.75 & 0 & 0 & 0 \\
\hline Arachidonic (20:4n6) & 1.06 & 0.51 & 0.63 & 0.86 & 0 & 0 & 0 & 0 & 0 & 0 & 0 & 0 \\
\hline $\begin{array}{l}\text { cis-13,16-Docosadienoic } \\
(22: 02)\end{array}$ & 0 & 0 & 0 & 0.73 & 0 & 0 & 0 & 0 & 0 & 0 & 0 & 0 \\
\hline $\begin{array}{l}\text { cis-5,8,11,14,17- } \\
\text { Eicosapentaenoic (EPA) } \\
(20: 5 n 3)\end{array}$ & 0 & 0.3 & 0 & 0.51 & 2.49 & 0 & 0 & 0 & 0 & 0 & 0 & 0 \\
\hline Total & 41.67 & 46.43 & 37.8 & 105 & 28.96 & 14.43 & 42.25 & 36.58 & 49.28 & 27.67 & 8.72 & 18.21 \\
\hline
\end{tabular}

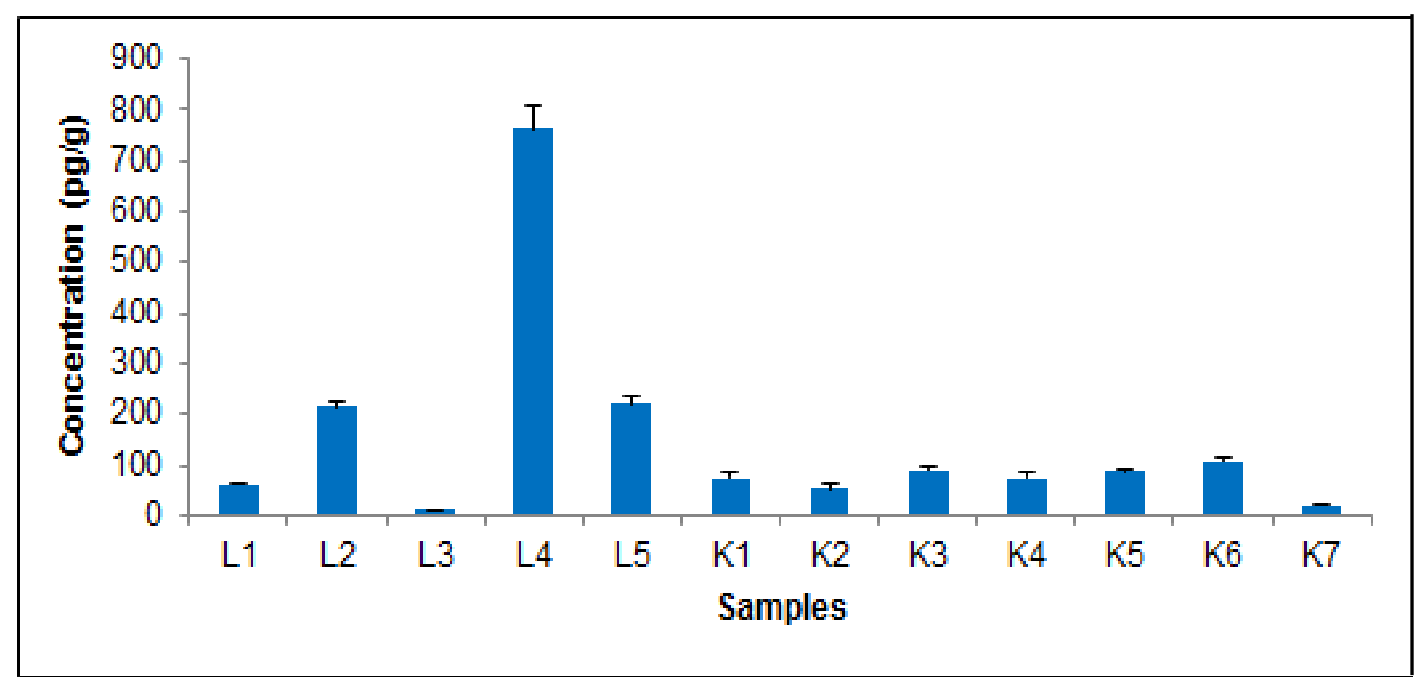

Figure 4. Carotenoid content of sea cucumber Karimunjawa (K) and Lampung (L) waters (L1, L2 : Stichopus sp.; L4 : Holothuria sp.; L3, L5 : Actinopyga sp.; K 1, 2,3, 6 : Stichopus sp.; K4 : Stichopus vastus; K5 : Stichopus ocellatus; K7 : Actinopyga lecanora). 


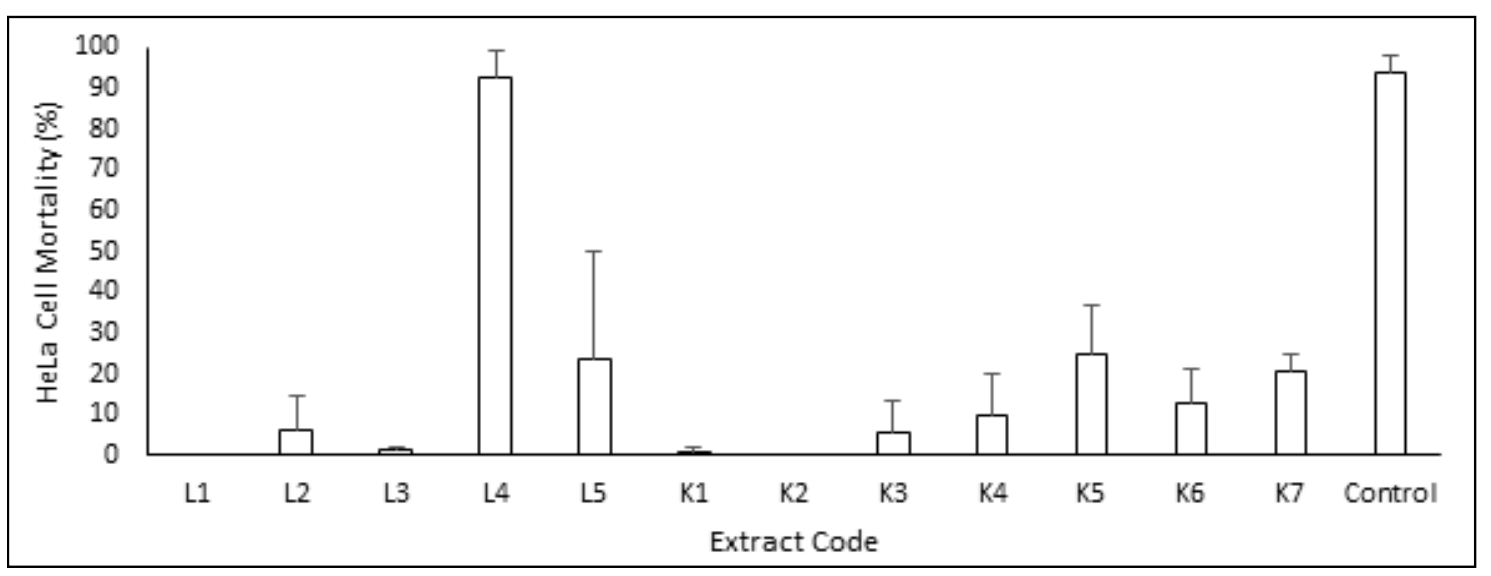

Figure 5. Cytotoxicity of sea cucumber extract Karimunjawa (K) and Lampung (L) waters (L1, L2: Stichopus sp.; L4: Holothuria sp.; L3, L5: Actinopyga sp.; K 1, 2,3, 6: Stichopus sp.; K4: Stichopus vastus; K5: Stichopus ocellatus; K7: Actinopyga lecanora) against HeLa cell at concentration of 30 ppm; control used was doxorubicin in concentration of $5 \mathrm{ppm}$.

Lampung surrounding waters, locally known as teripang kapuk or kelapa, had the lowest carotenoid content while sample L4 (Holothuria $\mathrm{sp}$ ) was the highest. This result may suggest the biopotency of $\mathrm{L} 4$ samples. Carotenoid compound is the $\mathrm{C}_{40}$ skeleton of the parent tetraterpene that have been modified by chemical transformations such as oxidation or cyclization. Carotenoid visually can be detected from the yellowish -reddish yelow color which absorbs visible light at $400-450 \mathrm{~nm}$.

\subsection{In Vitro Anticancer Activity}

Figure 5 showed the cytotoxicity result of sea cucumber extract against HeLa cancer cell-line at concentration of $30 \mathrm{ppm}$. Sea cucumber extract with code L4, i.e Holothuria sp., showed the best cytotoxic activity against HeLa cell, almost comparable with the $5 \mathrm{ppm}$ doxorubicin, a commercial anticancer agent used as control. This is an agreement with the carotenoid data, where the highest carotenoid was from Lampung sea cucumber L4 Holothuria sp.

Further study as showed in Figure 6 indicated that this Holothuria sp. extracts were active against 4 cancer cell lines, i.e colon (WDr), cervix (HeLa), and breast ( T47D and MCF-7). At low extract concentration (5 ppm), HeLa and WDr cells were more sensitive to L4 extract, suggesting that it was significant statistically $(p<0.05)$. While at higher concentration, the sensitivity toward L4 extract among the 4 tested different cells were relatively similar $(p>0.05)$; the extract could kill $100 \%$ all cells tested. It means that in concentration of extract higher than $5 \mathrm{ppm}$, the extract contain relatively high active substances that

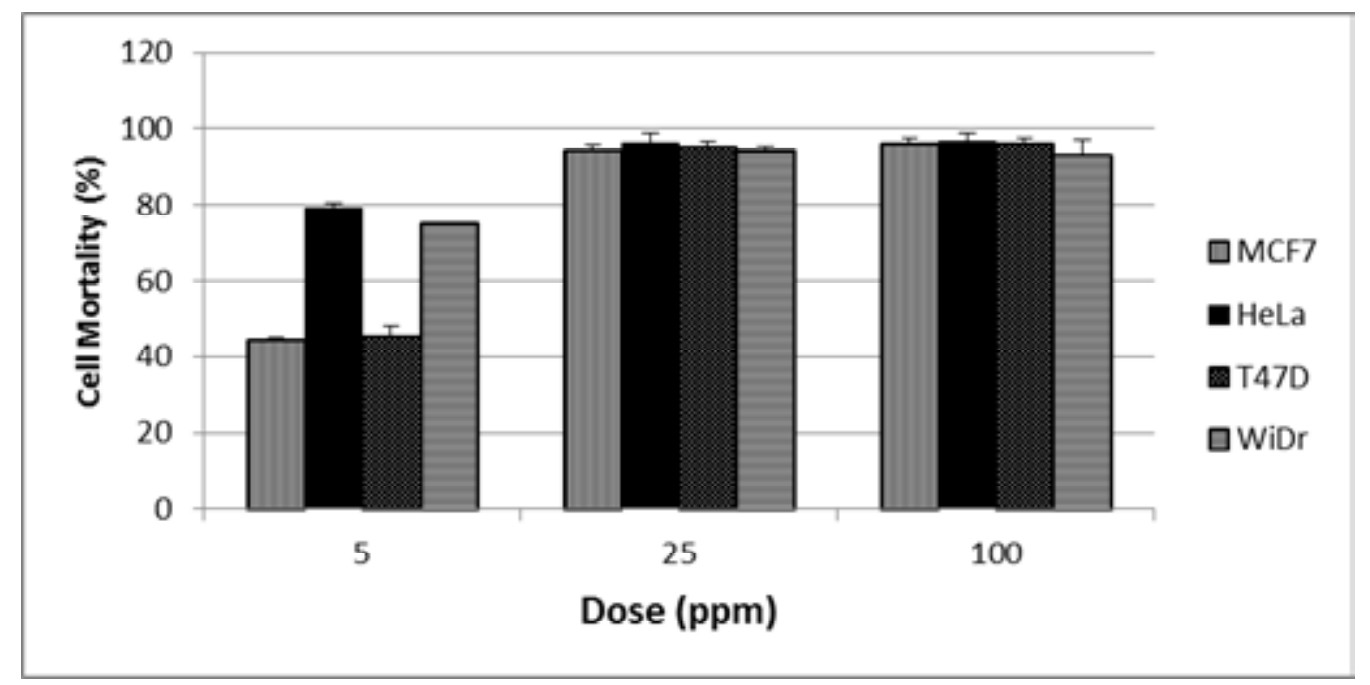

Figure 6. Dose response of Holothurian extract (L4) against four cancer cell lines. 


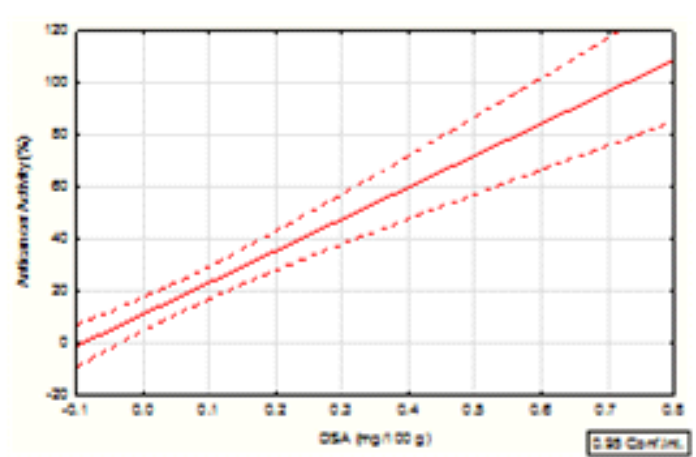

(a)

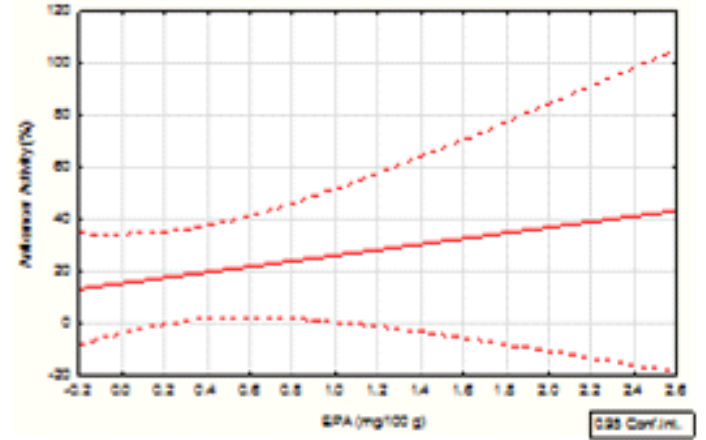

(b)

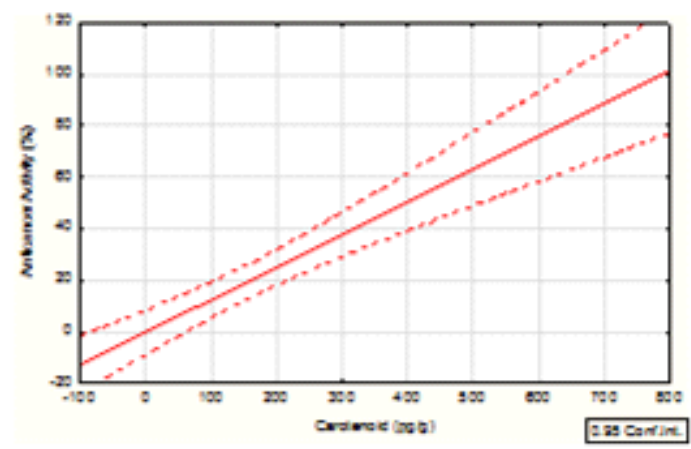

(c)

Figure 7. Partial bivariate regression between cis-13,16-Docosadienoic/DSA (a), cis-5,8,11,14,17Eicosapentaenoic/EPA (b), and carotenoid (c), to sea cucumber cytotoxicity against HeLa cell lines.

was very toxic to all cells. From that Figure, it can be concluded that the $\mathrm{IC}_{50}$ value will be reached when the dosage of 1-10 ppm extracts applied.

\subsection{Relationship between Fatty Acids and Carotenoid Profile to Cytotoxicity}

Multivariate stepwise regression analysis revealed three variables (cis-13,16-Docosadienoic/DSA, cis5,8,11,14,17-Eicosapentaenoic/EPA, and carotenoid content) significantly $(\mathrm{P}<0.05)$ contributed to the value of cytotoxicity. Combination of these three variables determined $89.22 \%\left(R^{2}=0.89\right)$ to the value of cytotoxic activity against HeLa cell lines. Partial bivariate regression analyses from these three variables to cytotoxicity are shown in Figure 7 . It is shown that combination of DSA $\left(R^{2}=0.88\right)$ and carotenoid content $\left(R^{2}=0.84\right)$ was the major partial contributor in cytotoxicity. Meanwhile, EPA contributed weakly, as the partial regression bivariate analyses only showed weak determination value $\left(R^{2}=0.07\right)$.

These results may contrary to common finding that omega-3 PUFA and omega-9 MUFA are the major fatty acids that play the most important role to keep heart healthy and minimize cancer risk (Jing et al. 2013). PUFAs especially omega ( $n$ or $\omega$ ) -3 fatty acidseicosapentaenoic $(20: 5, n-3) \quad$ (EPA) and docosahexaenoic (22:6, n-3) acid (DHA) are believed to cause the lowering of the incidence of thrombosis and atherosclerosis. This study found other compound (cis-13,16-Docosadienoic) significantly enhance, comparing to EPA, the ability of extract against HeLa cell lines. It is probable, specificity of cell lines that had been used affect the results of cytotoxic activity. A particular cytotoxic compound may effects vary, against different cell lines. Other study in cytotoxic activity of non-polar fraction from sea cucumber also showed varied results. Nursid et al. (2016) reported that steroid was the active compound suspected in sea cucumber Actinopyga sp. which its methanolic extract was able to inhibit WiDr and T47D cell lines viability with the $L_{50}$ value of 55.93 and $87.55 \mu \mathrm{g} / \mathrm{ml}$, respectively. Further study on the fractionation and cytotoxicity evaluation of the Holothuria sp from Lampung waters found that the most active compound was stearic acid with $\mathrm{IC}_{50}$ of $10.32 \mathrm{ppm}$ towards MCF7 cells (Januar, Nursid, \& Chasanah, 2014). Moreover other fatty acid, such as arachidonic acid, has been reported to take an important role for human growth, blood cloting and wound healing. Arachidonic acid is also known as precursor of eicosapentanoic and primary compound of cell membrane. In general, fatty acids and carotenoid are prospective anticancer agents. Therefore, sea cucumber, particularly the 
Holothuria sp harvested from Lampung waters in this study, is the most prospective raw material for nutraceutical or functional food ingredient with anticancer potency.

\section{Conclusion}

This study support previous report that PUFA was the dominant fatty acid in the 12 sea cucumber studied. Holothuria sp from Lampung contained the highest PUFA among the sea cucumber studied. Of the 12 sea cucumber harvested from Lampung and Karimunjawa waters, the Stichopus sp (sample L4) also exhibited the highest cytotoxicity against 4 cancer cell lines, i.e colon (WDr), cervix (HeLa), and breast (T47D and MCF-7). At low extract concentration (5 ppm), HeLa and WDr cells were more sensitive to L4 extract. This cytotoxic ability against cancer cell lines was supported by its carotenoid content. Combination of cis-13, 16 docosahexaenoic acid and carotenoid was the major partial contributor of L4 anticancer activity. These finding suggest that Holothuria sp harvested from Lampung waters was potential to be used as raw material for nutraceutical products.

\section{References}

Aidin, M., Sevgili, H., Tufan, B., Emre, Y., \& Köse, S. (2011). Proximate composition and fatty acid profile of three diferent fresh and dried commercial sea cucumber from Turkey. Int. J. of Food Science and Technology $46: 500-508$.

Bordbar, S., Farooq, A., \& Nazamid, S. (2011). High-value components and bioactives from sea cucumbers for functional foods-A Review. Mar. Drugs, 9, 17611805.

Dang, N.H., Thanh, N.V., Kiem, P.V., Huong, M., Minh, C.V., \& Kim,Y.H. (2007). Two new triterpene glycosides from the Vietnamese sea cucumber Holothuria. Arch. Pharm. Res. 30 (11), 1387-1391.

Darsono, P. (2007). Teripang (Holothurioidea): Kekayaan alam dalam keragaman biota laut. J. Oseana XXXII (2): 1-10.

Ebada, E.S., Edrada, R.U., Lin, W., \& Proksch, P. (2008). Methods for Isolation, purification and structural elucidation of bioactive secondary metabolites from marine invertebrates. Nat. Prod, 3(12): 1820-1831.

Fawzya, Y.N., Januar, H.I., Susilowati R., \& Chasanah, E. (2015). Chemical composition and fatty acid profile of some Indonesia sea cucumbers. Squalen: Bulletin of Marine and Fisheries Postharvest and Biotechnology, 10(1): 27-34.

Ibrahim, H.A.H. (2012). Antibacterial carotenoids of three Holothuria species in Hurghada, Egypt. The Egyptian Journal of Aquatic Research, (38), 185-194.

Janakiram, N.B., Mohammed, A., \& Rao, C.V. (2015). Sea cucumbers metabolites as potent anti-cancer agents. Mar. Drugs $13: 2909-2923$.

Januar, H.I., Nursid, M., \& Chasanah, E. (2014). Cytotoxic saturated fatty acids from the Indonesian sea cucumber Holothuria sp. Squalen Bulletin of Marine
\& Fisheries Postharvest \& Biotechnology, 9 (1), 11 15.

Jensen, S.K. (2008). Improved Bligh and Dyer extraction procedure. Lipid Technol, 20(12):280-281.

Jing, K., Wu, T., \& Lim, K. (2013). Omega-3 polyunsaturated fatty acids and cancer. Anticancer Agents Med Chen, 13(8): 1162-77

Lichtenthaler, H.K., \& Buschmann, C. (2001). Chlorophylls and Carotenoids: Measurement and Characterization by UV-VIS Spectroscopy. Current Protocols in Food Analytical Chemistry F4.3.1-F4.3.8. John Wiley \& Sons, Inc.

Neto, R.R., Wolff, G.A., Billet, D.S.M., Mackenzie, K.L., \& Thompson, A. (2006). The influence of changing food supply on the lipid biochemistry of deepsea holothurians. Deep-sea Research 1, 53.

Nursid, M., Maharani, A.P., Riyanti, \& Marraskuranto, E. (2016). Cytotoxic activity and secondary metabolite characteristics of sea cucumber Actinopyga sp. Methanolic extract. Squalen Bull. of Mar. and Fish. Postharvest and Biotech. 11 (1): 23-30.

O'Fallon, J.V., Busboom, J.R., Nelson, M.L., \& Gaskins, C.T. (2007). A direct method for fatty acid methyl ester synthesis: Application to wet meat tissue, oils and feedstuffs. J. Anim.Sci. 85: 1511-1521.

Pérez-Espadas, A.R., Verde-Star, M.J.,Rivas-Morales, C., Oranday-Cárdenas, A.,Morales-Rubio, M.E., LeónDeniz, L.V., Canul-Canché, J., \& Quijano, L. (2014). In vitro cytotoxic activity of Isostichopus badionotus,a sea cucumber from yucatan peninsula coast. Journal of Pharmacy and Nutrition Sciences, 4: 183-186.

Ridhowati, S., Zakaria, F., Syah, D., \& Chasanah, E. (2014). Sea cucumber as anticancer agents and Its development for functional food products. Squalen Bulletin of Marine \& Fisheries Postharvest \& Biotechnology, 9 (2): 85-96.

Ridzwan, B.H., Hanita, M.H., Nurzafirah, M., Norshuhadaa, M.P.S., \& Hanis, Z.F. (2014). Free fatty acids composition in lipid extracts of several sea cucumbers species from Malaysia. International Journal of Bioscience, Biochemistry and Bioinformatics, 4(3): 204-207.

Svetashev, V.L., Levin, V.S., Cham, N.L., \& Do, T.N. (1991). "Lipid and fatty acid composition of Holothurians from tropical and temperate waters," Comp. Biochem. Physiol., vol. 4, pp. 489-494, 1991.

Sicuro, B., Piccino, M., Gai, F., Abete MC., Danieli A., Dapra F., Mioletti S., \& Vilella, S. (2012). Food quality and safety of Mediterranean sea cucumbers Holothuria tubulosa dan Holothuria polii in Southern Adriatic Sea. Asian J. Anim. Vet. Adv. : 1-9.

Vergara, W., \& Rodríguez, A. (2016). Nutritional composition of sea cucumber Isostichopus sp. Natural Resources, 7: 130-137.

Vaughan, V.C, Hassing, M-R., \& Lewandowski, P. A. (2013). Marine polyunsaturated fatty acids and cancer therapy. British Journal of Cancer (2013) 108, 486492.

Yoo, YC1., Shin, B.H., Hong, J.H., Lee, J., Chee, H.Y., Song, K.S., Lee, K.B. (2007). Isolation of fatty acids with anticancer activity from Protaetia brevitarsis larva. Arch.Pharm.Res. 30(3): 361-365.

Wen, J1., Hu, C., \& Fan, S. (2010). Chemical composition and nutritional quality of sea cucumbers.J. Sci Food Agic 0(14): 2469-74.

WHO. 2014. Cancer country profiles 2014-Indonesia. 